\title{
Children of the forests: Child gatherers and traders in non- wood forest products in the Mazowe Valley area in Zimbabwe
}

\author{
Vincent Mabvurira ${ }^{1^{*}}$, Jabulani Calvin Makhubele ${ }^{2}$ \\ ${ }^{I}$ Department of Social Work, University of Zimbabwe; ${ }^{2}$ Department of Social Work, University of Limpopo \\ * Corresponding Author: Vincent Mabvuriral, ${ }^{1}$ Department of Social Work, University of Zimbabwe, P. O Box MP167MT \\ Pleasant HARARE, Zimbabwe._E. mail:vmabvurira@sociol.uz.ac.zw
}

(Received 19 December 2017; Accepted 20 February 2018; Published 5 May 2018)

\begin{abstract}
Non-wood forest products play a stupendous role in the lives of many people across the globe. The products contribute immensely to household economies as they are either consumed or sold. The object of this study was to give an account of child gatherers of non-wood forest products in the Mazowe Valley area in Zimbabwe. The study adopted a qualitative approach in which data were gathered from 27 children through participant observations and informal interviews. Children were found to actively participate in the collection and trading of non wood forest products. Child collectors of the products are ranged in age from 4 to 17 years. Some of the children lived in child headed households while some lived with their parents. The NWFPs collected include fodder, small animals, insects, mushroom and wild fruits. Income realized from the sale of the products was used for buying food, clothes, goodies, and paying school fees. It is therefore concluded that non-wood forest products contribute towards poverty reduction, enhance well-being and capabilities, ascertain livelihood adaptation, vulnerability and resilience and natural resource base sustainability.
\end{abstract}

Key Words: Non-wood forest products, children, child poverty, child food poverty 


\section{Introduction and background to the study}

Throughout the developing world, forests form an integral part of the rural economies supplying food and trade items. Gathering of Non-Wood Forest Products (NWFPs) is an important element in the livelihoods of most rural communities across the globe. Vantomme (2003) notes that at global level, more than two billion people are dwelling in forests, depending on non-wood forests products for subsistence, income and livelihood security. NWFPs are considered to be important for sustaining rural livelihoods, reducing rural poverty, biodiversity conservation, and facilitating rural economic growth (Global NTFP Partnership, 2005). According to Stryamets (2012) forests provide a diversity of non-wood forest products as a resource base for regional and rural development. The role of non-wood forest products differs in time and space. In addition, several opportunities for improved rural development are linked to NTFP (Adepoju, 2007). The NWFPs are either consumed or sold to raise income for other uses. In Lao NWFPs contribute $50 \%$ to food security compared to rice the staple food and 40-50\% of cash income for rural households (Vongkhamsao, 2006). NWFPs have a high industrial and trade value (Vongkhamsao, 2006). In some cases, non-wood forest products are exported. These forest products contribute substantially to national economic growth through urban, national and international markets (FAO, 1995; Ibrahim, Abdalla \& Fangama, 2015). The vast majority of NWFPs are consumed directly by the people who collect them (Glover \& Glover, 2014). This suggests that NWFPs contribute significantly to food security of some families. This is so because in most cases they are collected for free and the only effort required is that of collecting and selling them.

According to FAO (1995; 1999), NWFPs consist of goods of biological origin other than wood, as well as services derived from forests and allied land uses. NWFPs include all products that are derived from the forests with the exception of timber. These include plants, animals, and fungus species used for fuel, food, medicine, forage and fibers that include products that have valuable chemical components or that are used for ritual purposes. However, the term excludes all woody raw materials. NWFPs have also been called minor forest products, other forest products, other economic products or non-timber 
forest products (Glover \& Glover, 2014). There are also NWFPs of animal origin that include bushmeat like birds, insects, small animals and trophies. Meat collected from the forests is an important food item in some families in the developing world. In areas where other forms of meat are not readily available to the people, bush meat may be the only animal protein source that is handy and affordable (Glover \& Glover, 2014).

According to Glover and Glover (2014), appropriate management and sustainable harvesting of such resources have a major role to play in food security. NWFPs are important in relieving hunger periods in the agricultural cycle and in smoothing out other seasonal fluctuations (FAO, 1995). They are also critical in employment creation. A lot of people are employed in the NWFPs chain from collection, distribution and marketing. Poor households in particular depend on these products for their livelihood because they usually have more access to forests than other resources (FAO, 1995). In most circumstances, women rely more on NWFPs than men. This is mainly because women are responsible for household activities than men. Generally products which contribute through direct consumption are under the control of women of which products which have indirect contribution through income generation are taken by men.

According to FAO (1995:2), NWFPs are important to three main groups;

- rural populations (the largest group) who have traditionally used these items for livelihood, social and cultural purposes,

- urban consumers (a smaller but fast growing group ) who purchase these items,

- traders and product processors who rely on urban consumers for markets.

Generally NWFPs benefit poor people and are an incentive for forests conservation. According to Neumann and Hirsch (2000), there is strong evidence that the poorest of the rural poor are most dependent on NWFPs. Majority of NWFPs are traded in small quantities per producer though collective quantities can be large. They have an advantage in that they may be used without or with little processing using simple technology. Rural poor may rely on them when crops fail or when households are hit by shocks such as unemployment, death or disease. However according to Neumann and Hirsch (2000), NWFPs can be poverty traps in that people rely on them because they are poor and do not have better alternatives but they are unable to use these resources to get out of poverty. 
The consumption of wild foods provide essential vitamins and minerals for the client because of their richness in vitamins and variety of minerals. Insects, caterpillars and wild rodents constitute good sources of protein. Many forest fruits are valued as food for children and are collected by children in the forests. Women and children mostly collect wild vegetables. In a study by Ibrahim, Abdalla and Fangama (2015) in South Kordofan State (Sudan), 61.7\% of households indicated that income from NWFPs satisfied their needs. In support of that Stryamets (2012) concluded that local populations in forested regions have used NWFPs for domestic and economic purposes for centuries, and continue to do so. The traditional knowledge about different NWFPs, collection methods, processing, storage, and use, which have been passed through generations, was deeper among local people.

Though a lot has been written concerning the collection and trading of NWFPs, there is scanty literature focusing on the collection by children, the contribution of NWFPs in child headed household economies and challenges faced by children in the collection and trading of NWFPs. This study therefore sought to profile child gatherers of NWFPs, document types of NWFPs collected and the use of income realized from selling the products by children in the Mazowe valley area, in Zimbabwe. The authors are cognizant of the fact that children experience poverty differently from adults.

\section{Theoretical framework}

The study was informed by the ecological approach as its theoretical framework. According to Angus and Pilot (2000), the ecological approach places the child at the centre

of the family, neighborhoods, and wider structural and cultural circumstances such as government policies and prevailing social and cultural norms. Ecological approach is an ideology that was brought up to understand better the effects of the environment within which a child resides, that is both positive and negative. This approach brings forth four levels of influence in a child's life which are; individual, family, neighborhood and macro cultural levels. 
At the individual level a child may be made vulnerable due to internal conflicts that may result in them feeling socially isolated. According to Finkelhor (2008), experiences such as loss, conflict, deprivation or turmoil within the home may undermine a child's ability to protect themselves, making them a potential target for exploitation. This level mainly focuses on the child and parents or caregivers. Parents and caregivers have the primary responsibility to protect their children from harm yet this has been compromised by socio-economic problems such as unemployment, poverty and low income. The second level consisting of the family is affected by factors including socio-economic status, marital status and partner arrangements, wider family support, and health status of caregivers and other family members (Wynd, 2013). These families may sometimes face stressors such as family disruption, health and emotional problems, substance abuse and financial complications. Traditionally when such situations arose the extended family would assist but due to modernization and economic hardships people are more concerned about their immediate nuclear family hence leaving more children vulnerable to sexual exploitation.

The third level is that of settings surrounding the child that is the neighborhood and local circumstances including fundamental customs about the treatment and status of children, and economic and social conditions together with access to employment. The macro-systems examine the larger societal factors that influence child abuse and these include cultural norms that support violence as an acceptable way to resolve conflicts, norms that give priority to parental rights over child welfare, and norms that entrench male dominance over women and children (Dahlberg and Krug, 2002).

\section{Child poverty in Zimbabwe}

Zimbabwe is a low income country situated in Southern Africa. Poverty and deprivation in the country date back to the colonial period during which the whites benefited at the expense of blacks. After independence in 1980, poverty persisted mainly due to maladministration of the country. The country plunged into economic crises between 1990 and 2008. The crisis reached its peak between 2000 and 2008 and left many citizens poverty stricken. The situation in Zimbabwe has also been worsened by recurrent droughts, 
and HIV and AIDS which have robbed many families of their breadwinners. This reduced the capacity of poor families to provide for their children. Hence child poverty is not a rare phenomenon in Zimbabwe. After the peak of HIV and AIDS between 1990 and 2000 many children were left orphaned and lived in child headed households, elderly headed households or with relatives. Rural areas have higher incidence of child poverty (UNICEF, 2010). Average food deprivation affects more than $12 \%$ of children (ibid).

Child poverty in Zimbabwe is predominantly a rural phenomenon although in some parts of the country, urban poverty is notably high (UNICEF, World Bank \& ZIMSTATS, 2015). UNICEF, World Bank and ZIMSTATS (2016) also note that just like poverty in general, food poverty is high in rural wards compared to urban wards. The situation has been worsened by the government's poor capacity to cope with socio-economic challenges haunting the country. There are no comprehensive social protection programmes to cushion children against child poverty. Though development partners have complimented the government in child welfare programming most children from poor families continue to wallow in poverty.

\section{Study area}

This article is based on a study carried out in Mazowe district, Mashonaland Central Province in Zimbabwe. Mazowe district has an average poverty prevalence of $67.6 \%$ (UNICEF, World Bank and ZIMSTATS, 2015). The district has 33 wards of which 13 are in Chiweshe communal areas and the rest are in resettlement areas. The district has a total surface area of 453,892 hectares and a total population of 233450 (ZIMSTATS, 2012).

\section{Methodology}

Methods of data collection involved use of qualitative approach (using an exploratory case study design) in the form of participant observation and unstructured informal interviews. Case studies explore and investigate contemporary, real life phenomenon through detailed contextual analysis of a limited number of events or conditions and their relationships (Zainal, 2007). Data collection was carried out between August 2016 and January 2017. The researchers targeted children who gathered or sold NWFPs at various points in Mazowe district. The study used convenience sampling in the sense that only the children 
whom the researchers came across during the study period formed part of the study sample. One of the researchers is home in Mazowe district hence was familiar with the NWFPs found in the area, where they are collected and the selling points. This made identification of study participants feasible. Informal interviews usually form part of participant observation that is usually more like a casual conversation between acquaintances. In participant observation, the researcher participates in naturally unfolding events and observes them as carefully and as objective as possible. Data were analysed using Thematic Content Analysis.

\section{Results}

\section{Description of study participants}

The population of the study comprised children who collect and sell NWFPs. A total of 27 children were identified. The lowest age was four years while the highest age reported was 17 years. The mean age was 9 years, suggesting that very young children are actively involved in the collection and selling of NWFPs. However it was also found that in some cases, children work with adults in the collection and selling of NWFPs. Of the 27 children 19 were boys while 8 were girls. A higher number of boys than girls reported collecting NWFPs for sale ( 8 and 3 respectively). Generally girls collected them for consumption while boys collected them for both consumption and sale. The children generally came from poor families among former commercial farm employees and small holder farmers settled under the Fast Track Land Resettlement Programme in Zimbabwe. Most of the children (15) had both parents living, 7 were single orphans while 5 were double orphans and 4 lived in child headed households. Most of the children (17) were out of school and of these 3 had never been to school. Findings of the study suggest that generally children from poor families are actively involved in the collection and sale of NWFPs. 


\section{Types of NWFPs}

The child participants reported collecting various NWFPs which included fodder, insects, small animals, honey, wild fruits and mushroom.

\section{Fodder}

The children reported collecting various types of wild vegetables which were served as side dishes (relish) with thick porridge (sadza/pap) which is the staple food for Zimbabwe. These wild vegetables included nyevhe (spider wisp), derere (traditional okra), bonongwe (poor man's spinach), and mubvunzandadya (wild spinach). The majority of the children (22) reported that they use wild vegetables for own consumption than for sale. The fodder is mostly gathered during the rainy season and is the main form of side dish for some families. One male child who stayed with his neglect father reported that:

"I collect bonongwe to eat with sadza, if I don't, my father doesn't care as he will be at the bar drinking”.

In another statement another child said:

"In summer, garden vegetables don't do well and fodder is the only cheap alternative as we can't afford to buy relish all the time".

The children indicated that most wild vegetables are cheap to cook in that they do not require additional ingredients like cooking oil except salt. It was also found that some wild vegetables were dried for later consumption or sale. Some of the children also reported that some fodder had medicinal effect and were recommended for people with chronic conditionals like Diabetes Miletus. A good such example cited was tsine (black jack) which some health officials even recommended for people living with HIV and AIDS.

\section{Mushroom}

A number of children were identified selling mushroom near Mazowe dam along Harare Bindura highway. They were displaying and selling the mushroom to motorists. As reported by the participants, the place is known as a vending site for mushroom during the rainy season. The children competed with adults especially women in selling the 
mushroom. The participants reported collecting the mushroom from the forests and mountains surrounding the Mazowe dam. They go into the forests to scavenge for the mushroom especially early in the morning. The child participants also reported consuming the mushroom as relish in their own homes. Some even indicated that they dry the mushroom for later consumption. It was reported that collecting of mushroom should be done carefully as some may be poisonous especially those that grow around areas with eucalyptus trees. The children reported that they realize an average of US\$2 on a bad day to US\$ 8 on a good day from the sale of mushroom. Their main challenge was competition from adults. It is also important to note that some of the children worked in collaboration with adults or siblings in the collection and selling process. For example one girl said:

"My brothers go into the forests to collect the mushroom and I do the selling ....."

Some of the children reported that they supply mushroom to their special clients at Mazowe semi-urban centre and residents at Mazowe mine.

\section{Insects}

A number of insects were collected by the children especially for own consumption. These included ishwa (flying termites), termites, various types of grass hoppers and caterpillars. Very few children (4) reported that they sometimes sell the insects especially ishwa. They indicated that they moved from house to house and at business centres selling the insects. One child who was identified selling ishwa highlighted that they trap them at night, roast them on fire, add salt and sell to people mostly those who will be drinking beer. Caterpillars (madora) are not common in Mazowe district though sometimes people can come across them in the forests. Almost all the insects are seasonal in that they are common during the rainy season.

\section{Wild fruits}

The children reported collecting various wild fruits and among them were snot apples, monkey oranges, prickly pears, sour plum, governor's plum, etc . Of interest were mazhanje (wild loquats) and masawu (ziziphus mauritiana) which were collected mainly for commercial purposes. In Zimbabwe, the masawu were collected in Muzarabani district while mazhanje were collected in nearby forests. The masawu thrive very well in arid and 
semi-arid areas hence some children reported boarding buses to collect them in Muzarabani area. They either went to the forests to collect the masawu or they bought them from Muzarabani residents for resale in Mazowe. The masawu are dried any they have a longer life span than mazhanje which are sold while fresh. Children were identified in business centres such as Glendale, Mazowe, Concession, Nzvimbo, Gweshe, Bare and Chaona selling the fruits. A 16 year old school dropout girl who is also a head of household reported that her family survived on selling masawu in Glendale. She reported selling the dried fruits throughout the season. This is what she said:

"I sell masawu at the market throughout the year. I buy them from Muzarabani and I sell them in small quantities for US\$0.50 and US\$1. That is our main source of income for the family"

Those who reported collecting wild loquats sold them mainly around November and December. Some children reported travelling to Harare to sell the loquats in the streets of the CBD.

\section{Small animals}

The child participants reported trapping various small animals and birds. Of interest among the animals were wild rodents which were mostly sold by the children despite their own consumption. The children trapped the rodents in large groups, they cooked them and add salt and chilli and sold them at beer drinking points to people who will be drinking opaque beer. Generally the younger children (below 10 years) were mostly active in the trapping of small animals. The trapping of the rodents is seasonal as it is done during the dry season which falls between May and September. Not much is realized from selling rodents. The children reported that trapping the rodents is laborious as they have to dig hard ground to find them. They also noted that they risk snake bites in the dry grass and arrest by officers from the Environmental Management Agency for stating veld fires as they sometimes burn dry grass to clear the forest. The rodent trappers are blamed for causing veld fires and may be arrested if found. The children also reported administering poison to trap the animals. This may pose health threat to people who buy the rodents for consumption. 


\section{Other products}

Very few children all of whom were boys confirmed collecting honey from the forests. However, none of them reported selling the honey. Some children reported collecting roots for some plants for consumption either cooked or uncooked.

\section{Use of income}

As noted earlier, some children sold some NWFPs. The use of income realized from the sale is indicated in the table below

\begin{tabular}{|l|l|}
\hline Use & No of children \\
\hline Buying food & 16 \\
\hline Buying clothes & 13 \\
\hline Paying school fees & 2 \\
\hline Buying goodies & 24 \\
\hline $\begin{array}{l}\text { Buying alcohol and } \\
\text { cigarettes }\end{array}$ & 9 \\
\hline Savings & 2 \\
\hline Buying school requirements & 3 \\
\hline
\end{tabular}

Some reported that they surrender whatever they realized from selling NWFPs to their parents or guardians. Of interest was a male child who indicated that his father demanded money for beer from him.

\section{Discussion}

A lot has been written around the collection and sale of NWFPs in most parts of the developing world. However not much has been written concerning the collection by children or their contribution to child headed households. The objectives of this study were therefore to profile child gatherers of NWFPs, document types of NWFPs collected and the use of income realized from selling the products by children in the Mazowe valley area, in Zimbabwe. Results of the study indicate that children from low income families in rural 
Zimbabwe are actively involved in the collection of NWFPs. Although earlier studies (Vongkhamsao, 2006; FAO, 2005) have shown that rural people collect NWFPs for sale, most of the children in the Mazowe Valley collected them for consumption. This supports a finding by Glover and Glover (2014) who note that the vast majority of NWFPs are consumed directly by the people who collect them. The fact that most children collect them for consumption might suggest high levels of food insecurity in rural Zimbabwe or might be due to the fact that children find them in very small quantities such that they may not be much left for sale after their own consumption. Consumption of NWFPs may also suggest that they may be the only readily available food stuffs as most of the children hail from poor households. Contrary to Stryamets (2012) that traditional knowledge about different NWFPs, collection methods, processing, storage, and use, which have been passed through generations, was deeper among local people, children in Mazowe may lack knowledge on processing and storage of NWFPs. NWFPs are of significant importance to child headed households as they supplement their diet especially when they are no easily available alternatives. This corroborates Glover and Glover (2014) who argued that NWFPs supplement dietary requirements among most forest people across the globe. However it is important to note that types of NWFPs found across Zimbabwe vary from place to place. In most cases their availability in influenced by local climatic conditions.

Given the importance of NWFPs in child headed rural households, there might be need for development practitioners and nutritionists to come up with improved methods of preserving the forest foods so that they may be consumed throughout the year. The variety nature of NWFPs from fruits, fodder, small animals and insects to honey may suggest a balanced diet for children who consume these products. However the biggest challenge is that these products are commonly found during the rainy season hence the children especially those from child headed households may suffer during the dry season which is longer than the wet season. It is there of paramount importance for development workers to find ways of adding value to these products. Where they are sold, strategies on improving the value chain must be explored.

NWFPs are of paramount importance to the household economies of children who gather these products. Most children in Mazowe district reported that they use income realized from the sale of NWFPs to buy food and goodies. This is in line with the argument 
that most collectors of NWFPs are poor people (Neumann \& Hirsch, 2000). Some of the children even used the money to pay school fees and buy clothes and school uniforms. It can therefore be argued that NWFPs play an important role in alleviating child poverty among rural communities in Zimbabwe. NWFPs might not be making meaningful contribution to the gatherers' households due to a number of factors, chief among them lack of processing facilities. None of the participants in the current study reported any form of processing of the products. They were sold raw and could not fetch good money.

Results of the study also suggest that some children are abused by their parents who demand all the income realized from the sale of NWFPs. There may be therefore an element of child labour associated with the collection and trading in non-wood forest products. The collection of NWFPs by children may suggest a lot around child welfare in Zimbabwe. From one angle it may be viewed as a form of child labour or a sign of child neglect. If one takes into consideration children welfare laws in Zimbabwe especially the Children's Act (Chapter 5:06), such children fit very well in the various categories of children in need of care. Such children may lose play, resting or school time whilst gathering NWFPs.

\section{Conclusion}

This study has found that children as young as four years are actively involved in the collection of nonwood forest products. Both boys and girls from poor rural families were actively involved in the collection of the products. The products collected included fruits, insects, fodder and small animals. Apart from their own consumption, the children also sold the products. It can be concluded that children in some rural communities in Zimbabwe are actively involved in the collection and trading of NWFPs. NWFPs may be a good source of livelihood for some poor rural child headed households in Zimbabwe as they are consumed or sold. More research therefore needs to be focused on the caloric contributions of these products to the diets of children in rural communities. Another question to be answered by researchers is whether the involvement of children in the collection and sale of NWFPs should be considered a form of child labour. Also equally important is whether these children would collect the products if they were well provided for by adults. 
Conflicts of Interest: The authors declare no conflict of interest.

\section{References}

Adepoju, AA \& Salau, AS. 2007. Economic valuation of non timber forest products (NTFPs) http://mpra.ub.uni-muenchen.de/2689/.

FAO.1995. Non-wood forest products for rural income and sustainable forestry. Food and Agricultural Organisation.

FAO. 1999> Towards a harmonised definition of non wood forest products. IN: Unasylva, Volume 50, 1999/3.

FAO. 2005. State of the world's forests 2005. In International trade in non wood forest products. FAO, Rome.

Glover, MK \& Glover EK. 2014. The role of non-wood forest products in poverty alleviation and food security in urban Ghana. Agriculture, Forestry and Fisheries 3 (4):307312. doi: 10.11648/j.aff.20140304.23.

Ibrahim, GA., Abdalla, NI \& Fangama IM .2015. Contributions of non-wood forest products to household food security and income generation in South Kordofan State, Sudan. International Journal of Current Microbiology and Applied Sciences 4 (6): 828832.

Neumann, RP \& Hirsch E. 2000. Commercialization of Non Timber forest products: Review and analysis of Research, Bogor: CIFOR (Indonesia).

Stryamets 2012. Use and governance of non wood forest products in transition and market economies: cases in Ukraine and Sweden. Sweden: Sveriges, Lantbruksunive (thesis).

UNICEF .2010. Child-sensitive social protection in Zimbabwe. Harare, UNICEF.

UNICEF, 2016. Child poverty in Zimbabwe: A Multiple Overlapping Deprivation Analysis of Multiple Indicator Cluster Survey 2014, Harare Unicef

Vantomme, P. 2003. Compiling statistics on non wood forest products as policy and decision making tools at the national level. The International Forestry Review, 5(2):156160 . 
Vongkhamsao V. 2006. The importance, role and value of Non-Wood Forest Product for Laotian food security, nutrition and livelihoods. Lao: National Agriculture and Forest Research Institute.

Zainal, Z. 2007. Case study as a research method. Jurnal Kemanusiaan bil.9, Jun 2007:1-6.

ZIMSTATS, UNICEF and World Bank 2015. Zimbabwe Poverty Atlas. Harare: Zimbabwe National Statistics Agency.

To cite this article:

Vincent Mabvurira, Jabulani Calvin Makhubele. 2018. Children of the forests: Child gatherers and traders in non-wood forest products in the Mazowe Valley area in Zimbabwe International Journal of Modern Anthropology. 2 (11): 48 - 62 DOI: http://dx.doi.org/10.4314/ijma.v2i11.2

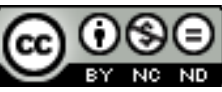

This article, as all articles published in this journal, is under The Creative Commons Attribution: Attribution-NonCommercial-NoDerivatives 4.0 International (CC BY-NC-ND 4.0). https://creativecommons.org/licenses/by-nc-nd/4.0/ 